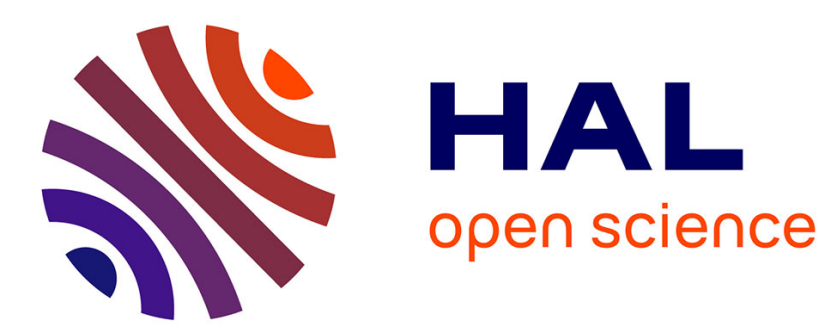

\title{
ORDERING PROCESS OF SPUTTERED AMORPHOUS THIN FILMS OF Al Mn UNDER THERMAL TREATMENTS
}

A. Chenoufi, B. Bouchet, J. Dixmier, C. Ecolivet

\section{- To cite this version:}

A. Chenoufi, B. Bouchet, J. Dixmier, C. Ecolivet. ORDERING PROCESS OF SPUTTERED AMORPHOUS THIN FILMS OF Al Mn UNDER THERMAL TREATMENTS. Journal de Physique Colloques, 1986, 47 (C3), pp.C3-485-C3-488. 10.1051/jphyscol:1986349 . jpa-00225761

HAL Id: jpa-00225761

https://hal.science/jpa-00225761

Submitted on 1 Jan 1986

HAL is a multi-disciplinary open access archive for the deposit and dissemination of scientific research documents, whether they are published or not. The documents may come from teaching and research institutions in France or abroad, or from public or private research centers.
L'archive ouverte pluridisciplinaire HAL, est destinée au dépôt et à la diffusion de documents scientifiques de niveau recherche, publiés ou non, émanant des établissements d'enseignement et de recherche français ou étrangers, des laboratoires publics ou privés. 


\title{
ORDERING PROCESS OF SPUTTERED AMORPHOUS THIN FILMS OF AI Mn UNDER THERMAL TREATMENTS
}

\author{
A. CHENOUFI, B. BOUCHET, J. DIXMIER and C. ECOLIVET \\ Laboratoire de Recherches Métallurgiques de I'INSA de Rouen, \\ UA CNRS $n^{\circ} 808, F-76130$ Mont-Saint-Aignan, France
}

\begin{abstract}
We report here preliminary results on an attempt to prepare $\mathrm{Al}-\mathrm{Mn}$ quasi crystalline thin films by cathodic sputtering. Starting from as deposited amorphous materials we have carried out successive in situ annealings of the sample in the electron microscope. The result is that, if moderate heating leads to crystalline phases, an a posteriori strong local irradiation by the electron beam can transform these crystals into a $\mathrm{T}$ phase with numerous defects.
\end{abstract}

\begin{abstract}
Résumé - Nous reportons ici des résultats préliminaires concernant la préparation de Al Mn quasicristallin à partir de couches minces fabriquées par pulvérisation cathodique. L'échantillon déposé amorphe est soumis à une succession de recuits dans le microscope électronique; cela induit, pour un chauffage modéré l'apparition de phases cristallines, qui lors de fortes irradiations localisées, par le faisceau d'électrons, se transforment en phase $\mathrm{T}$ avec de nombreux défauts.
\end{abstract}

\section{EXPERIMENTAL}

Thin films of about 1000 A thick have been prepared by $R$. F. cathodic sputtering.

The composition of the targets was chosen in order to obtain a film concentration ranging from 15 to 20 at $\%$ of $\mathrm{Mn}$ in the $\mathrm{Al}-\mathrm{Mn}$ alloy.

The nominal concentration of the as prepared samples was determined by the usual $X$ Ray fluorescence technique applied to the thin film case and was close to $20 \%$ at Mn. The $\mathrm{Na} C \mathrm{l}$ substrates have been cooled by $\mathrm{liquid}$ nitrogen and their temperature during the deposition was about $85^{\circ} \mathrm{K} / 1 /$.

The annealing procedure was performed by means of a small furnace in the electron microscope, step by step from $20^{\circ} \mathrm{C}$ to $400^{\circ} \mathrm{C}$ and then an additional $100 \mathrm{KeV}$ electron irradiation was applied localy by removing the diaphragm or increasing the electron beam current up to $45 \mu \mathrm{A}$ during a few minutes. A typical sequence is shown in figure 1 .

\section{RESULTS}

The films deposited on cold substrates are homogeneous and completely amorphous as detected through microdiffraction and imaging observations; see fig. 2 and 3 .

During the first annealing, step (A) at $150^{\circ} \mathrm{C}$ a nucleation of very fine grains takes place in the amorphous matrix giving a very dispersed and complex diffraction pattem; see fig. 4. 


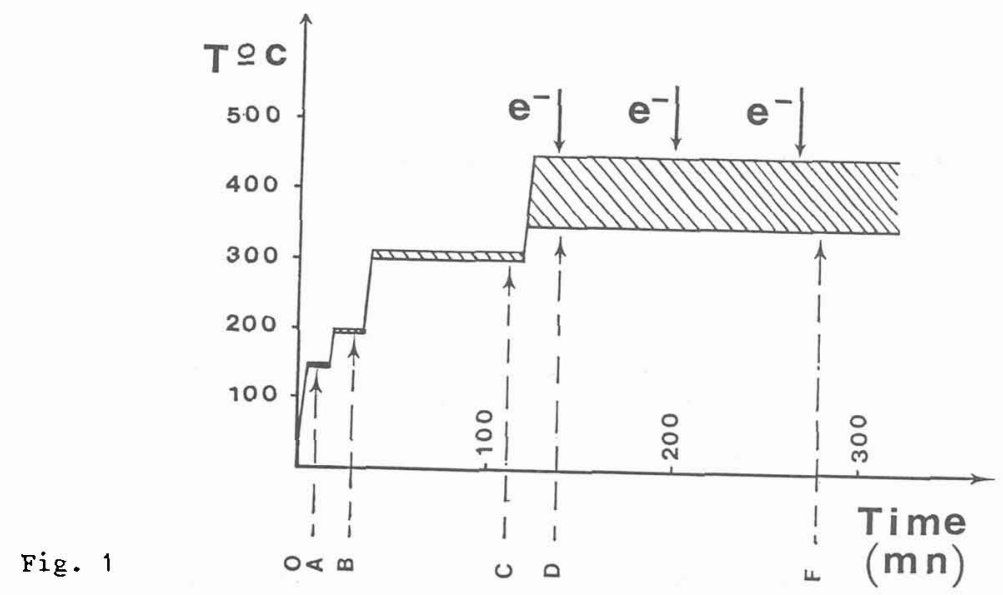

The most intense spots appear on the first halo of the amorphous diagram but no five fold symmetry axis can be revealed at the stage; see fig. 5 .

The next steps between 200 and $400^{\circ} \mathrm{C}(\mathrm{B}, \mathrm{C}, \mathrm{D})$ promotes a crystal growth of 2 separated phases, the one being $A 1$ and the other an intermetallic compound which is probably $\mathrm{Al}_{6} \mathrm{Mn}$.

Since no further transformations could not be achieved on normal heating the sample was then submitted to the electron beam irradiation as described previously. The intense local heating accompanied by strains produce drastic changes in the diffraction pattern which enlights a long range ordering process with a possible surstructure along well defined orientations.

This can be seen in fig. 6 and 7 where a dense set of spots are aligned on continuous strikes.

A more surprising effect of the irradiation is that instead of yielding a complete crystallisation of the material it can favor the growth of flower like objets which exhibit the diffraction pattern shown in fig. 8. The figures 9 and 10 are the dark field images corresponding to the first and the second almost regular decagon of the figure 8 .

If the now well known aspect of the 5 fold symmetry axis of the quasi crystalline state is obvious a carefull observation reveals special features which have not been mentionned before but elsewhere at this meeting (see Urban and al $/ 2 /$, Loiseau and al $/ 3 /$ ).

$1 /$ The decagoris and pentagons are deformed in such a manner that the spots are well aligned on continuous and equidistant strikes, but misaligned in the other directions

2/ The $1^{\text {st }}, 2^{\text {nd }}$ and $3^{\text {rd }}$ decagons are slightly elongated along this privilegied direction.

This diagram is very similar to that obtained by Urban and al (see fig. 9 of their paper) from precipitates in cast $A 1-M n$ alloys. These authors attribute such a pattern to a pseudo five fold axis of the $T$ phase (AP5).

Since the presence of the furnace in our electron microscope did not allow us to tilt the sample we could not identify the $T$ phase by its ten fold and two fold axes. It is to be noted that strikes have been already observed by L. Bendersky and al $/ 4 /$ but only on the 2 fold pattern of the $T$ phase. 

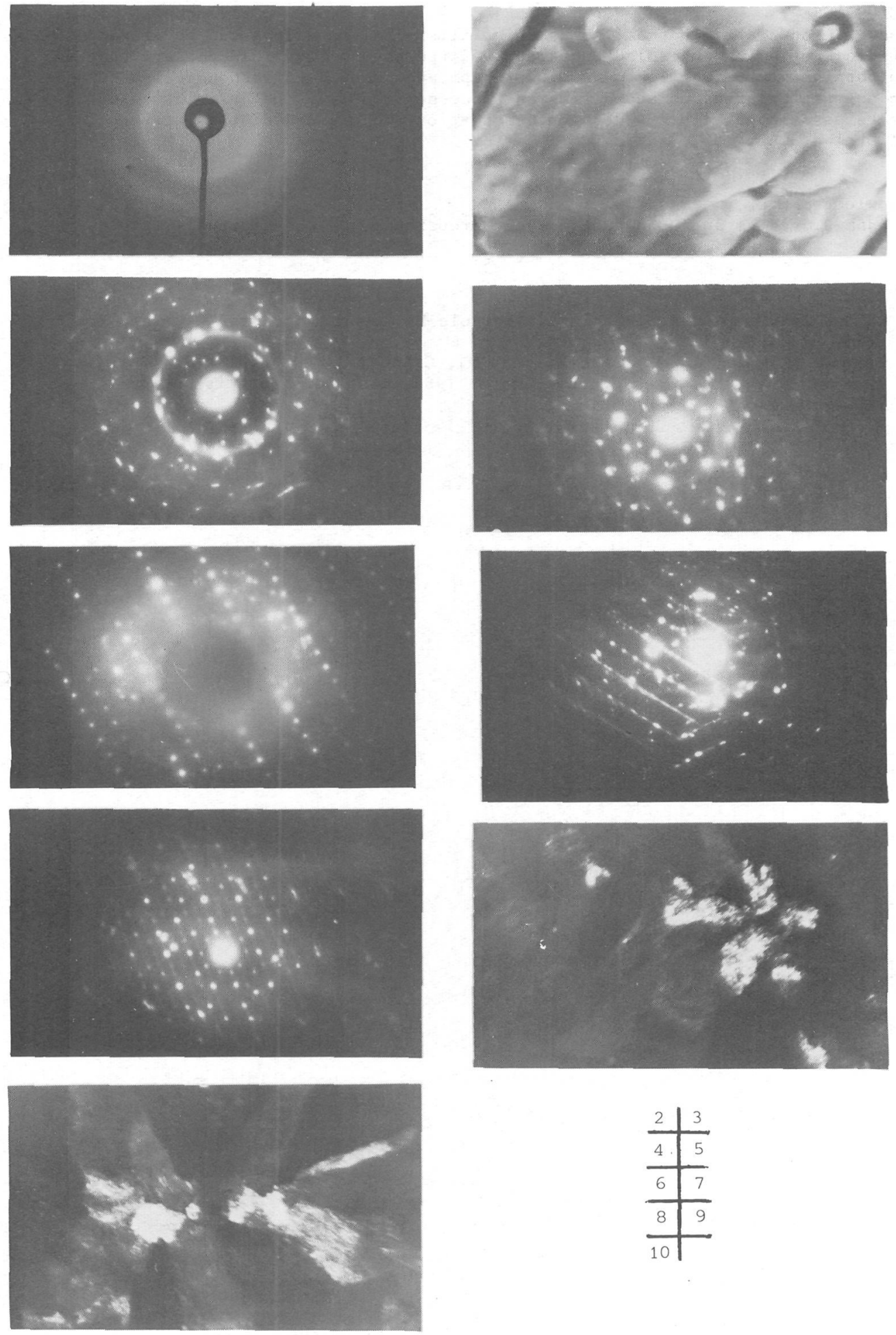

$$
\begin{array}{l|l}
2 & 3 \\
\hline 4 & 5 \\
\hline 6 & 7 \\
\hline 8 & 9 \\
\hline 10 &
\end{array}
$$




\section{CONCLUSIONS}

We have demonstrated that amorphous thin films of Al Mn alloys can be prepared by cathodic sputtering on cooled substrats. If the pseudo five fold pattern that we have obtained on flower like shaped precipitates should correspond to the $T$ phase (for energetical reasons and diffusion processes mostly), the description of the defects associated with the decagon deformation and the equidistant strikes is still to be done.

Acknowledgements

We thank $J$. Le Bas and $H$. Zeguib for the preparation of the amorphous samples.

\section{REFERENCES}

/1/ Le Bas J., Dittmar E., Protin L., Bernole M., Dubois D., Graf R., Thin Solid films 87 (1982) 195

/2/ Urban K., Mayer J., Rapp M., Wilkens M., Csanady A. and Fidler J., Workshop on Aperiodic Crystals, Les Houches, March 1986, elsewhere in this Journal

13/ Loiseau A. (private communication)

14/ Bendersky L., Phys. Rev. Lett., 55, $\mathrm{n}^{\circ} 14$ (1985) 1461 